\title{
The Rhine - a major fluvial record
}

\section{W.E. Westerhoff}

TN0 Geological Survey of the Netherlands. P0 Box 80.015, 3508 TA Utrecht, the Netherlands. Email: wim.westerhoff@tno.nl

Manuscript received: January 2008; accepted: January 2008

\begin{abstract}
This special issue contains the papers presented during the 2004 DEUQUA meeting. The papers provide an overview of recently carried out Quaternary geological studies on different aspects of the river Rhine system. The introductory paper follows the pathway of the Rhine downstream from its source in the Swiss Alps to the delta in the Netherlands. Along this route geological and geographical factors determine the regional subdivisions of the river: the Alps, the Upper Rhine Graben, the Rhenish Massif, and the Lower Rhine Embayment as part of the southern North Sea Basin. Each of these regions can be typified by a characteristic geological evolution.

New evidence from heavy-mineral analyses provides an improved lithostratigraphy and insight in the Quaternary evolution of the Rhine in the Upper Rhine Graben. The Plio-Pleistocene transition is determined by a palaeomagnetic study. The same paper emphasis on the impact of climate change on the composition of the magneto-mineralogy. Pollen analytical results show a complex interrelationship of a number of Middle Pleistocene interglacial periods in the northern part the Upper Rhine Graben. In the same area geomorphological analysis demonstrates a clear influence of tectonics on the preservation of fluvial terrace accumulations. A detailed pollen analytical study on the Late Glacial and Holocene development of the Rhine in the northern Upper Rhine Graben discusses the relation between vegetation cover and river behaviour. Finally, two papers from the Lower Rhine Embayment discuss a revised provenance based lithostratigraphy and its implications for understanding the fluvial history.
\end{abstract}

\section{A record of the Rhine}

With its length of $1320 \mathrm{~km}$ and a catchment area of 185,000 $\mathrm{km}^{2}$ the river Rhine is one of the larger rivers of NW Europe. Through the course of history the river forms a lifeline for the people of the Continent. The Rhine has played an important role in many historical events, it is the source for numerous myths, and has provided the inspiration for a rich cultural heritage. With respect to this the geological history of the Rhine shows even more diversity by the complex interplay of geological processes, such as: tectonic movements, fluvial and glacial processes and the imprint of the climatic history on the sedimentary record. Amongst them there is a wide variety of Quaternary geological subjects that were presented under the theme From source to Delta at the biannual DEUQUA meeting held at Nijmegen in 2004. The Rhine - a major fluvial archive formed the heading of a special session organised during this meeting. The present issue collects a number of papers resulting from that session.
Being one of the largest European river systems the Rhine provides a unique geoscientific dataset that offers the potential of bridging the gap between the Alpine glaciated areas and the inland ice-sheet advances of northern Europe. Apart from that, the deposits along the course of the river reveal a long history of fluvial and geomorphological processes during the Quaternary as well as from the preceding periods. This major record comprises a broad spectrum of tectonic, sedimentological, geomorphological, climate-stratigraphical and palaeontological evidence that can be used to understand the geological history of the river. However, of greater importance is that the record can show the responses of the river to changing external influences.

Like the geography and human history of the Rhine, the geological history shows a variable pattern of phenomena downstream from the Swiss Alps towards the debouchement in the southern North Sea. Following the pathway downstream Preusser (2008) provides a comprehensive overview of the geographical and geological factors that determined the 
subdivisions of the Rhine. Within the Alps the Rhine is influenced by complex interactions of tectonic and glacial processes. The main structural features of the West European rift system (Michon et al., 1963; Sissingh, 2006) determine the river's course through Germany and the Netherlands. Passing through the Rhenish Massif and the Lower Rhine Embayment, the Rhine has left a well documented flight of river terraces. Here also the influence of Quaternary volcanism in the Eifel region is well-registered in the fluvial record (Preusser, 2008). In the Netherlands the Late Tertiary and Quaternary deposits of the Rhine pass into the marine sequences of the southern North Sea Basin. During the Middle and Late Pleistocene glaciations the course of the river was influenced by major advances of ice-sheets entering the North Sea Basin (Busschers et al., 2005). As a result the Thames and Rhine flowed together on through the Strait of Dover via the Channel area to reach the Atlantic 0cean (Gibbard \& Lautridou, 2003). The Holocene delta of the Rhine in the Netherlands is formed as an interplay between upstream controls, subsidence, and sea-level rise (Gouw \& Erkens, 2007).

A number of papers in this issue address the fluvial record in the Upper Rhine Graben (URG). Provenance studies based of heavy mineral composition, use to provide a firm framework for the fluvial history. Not only the palaeo-sources (i.e. the Buntsandstein areas along the margins of the URG, the crystalline rocks of the Black Forest and Vosges, and the material of Alpine origin) but also prolonged periods of nondeposition, combined with soil-forming and weathering, demonstrate the importance of the heavy-mineral analysis (Hagedorn \& Boenigk, 2008). The spatial distribution of by specific heavy-mineral assemblages typified units demonstrates that tectonic movements played an important role on the shifting course of the Rhine throughout the Late Pliocene and into the Quaternary (Hagedorn \& Boenigk, 2008). A similar conclusion is drawn based on the research carried out on the fluvial terraces in the northern URG (Weidenfeller \& Kärcher, 2008). They show that the development of the 'Frankenthaler Terrasse' is largely controlled by differential tectonic movements, rather then by fluvial processes alone.

Palaeomagnetic analysis of long sedimentary and stratigraphically interpreted sequences can improve the age model for the Plio-Pleistocene fluvial deposits in the northern URG. However, in the absence of a thorough and consistent methodological approach problems may arise from this technique (Rolf et al., 2008). Of interest is the well-documented shift in magneto-mineralogy form goethite to greigite at the PlioPleistocene transition in a core from near LudwichshafenParkinsel. A feature that can be explained as a climate controlled impact on changes of the palaeoenvironment (Rolf et al., 2008).

Applying pollen analysis to the fluvial sequences in the northern URG has led to a more detailed insight in the thus far for hydrogeological purposes used stratigraphical subdivisions
(Knipping, 2008). Pollen evidence of the Mannheim-Interglacial formerly correlated with the Eemian, indicates that it should now be interpreted as part of the Cromerian Stage. The same holds true for the so-called Schifferstadt Interglacial. In addition, pollen analyses derived from the upper intermediate horizon (Obere Zwischen Horizont - OZH) can be assigned to at least four Mid-Pleistocene Interglacial periods. Within the lower half of the fluvial sequence in the northern URG, pollen assemblages can be correlated to part of the Tiglian A Substage (Knipping, 2008).

Palaeoenvironmental and vegetation changes in Late Glacial and Holocene deposits of the northern URG (Bos et al. 2008) show a similar development as those recorded in the Netherlands (Hoek \& Bohncke, 2002). The organic infill of palaeochannels demonstrates no complete deforestation during the Younger Dryas Stadial and a typical wet first half, followed by a drier second half of this phase. From the detailed reconstruction of the Holocene vegetation cover it can be concluded that differences of the substrate as well as regional differences in precipitation explain regional differences in the vegetation (Bos et al., 2008). Changes in the vegetation cover may also affect the sediment load of the rivers and in turn this can result in shifting river patterns. Similar processes have been recorded form more downstream situated sites in the Lower Rhine Embayment (Kasse et al., 2005).

The final two papers in this issue concentrate on the Upper Pliocene and Lower Pleistocene deposits of the Rhine in the northern part of the Lower Rhine embayment and the adjacent area in the Netherlands (Kemna, 2008; Westerhoff et al., 2008). These authors apply a refined lithostratigraphical framework for the fluvial history. In their study area the fluvial record is the result of a complex interplay between the main river systems of Rhine, Meuse and smaller rivers draining the southeastern part of Belgium. Tectonic factors seem to have a major control on the fluvial drainage patterns. Influxes of deposits from the Belgian rivers in the sequences already occur early in the Pleistocene while the Meuse continued to flow through the so-called East Meuse valley during a larger part of the Early Pleistocene. All in all these papers demonstrate that the age models applied to the Lower Pleistocene fluvial deposits are far from secure.

The papers presented bring together a variety of information on the Quaternary development at various sites along the Rhine. In part they demonstrate the complexity of this major fluvial archive. However, in time as well as in space, many parts of this record are poorly known and need to be unravelled before we can develop a strong concept for understanding the river system at the catchment scale. Consequently, this emphasises the need for more data and improved geological correlation. This will require further integration and co-operation between European geoscientific working groups that are active along this great river that so strongly inspires the imagination of many people. 


\section{Acknowledgement}

Prof. Dr Jef Vandenberghe, Dr Kees Kasse and Dr Ronald Van Balen are thanked for their encouragement and support through their organisation of the special session on the river Rhine system during the 2004 DEUQUA meeting Kees Kasse and Wim Hoek (editors of the Netherlands Journal of Geosciences) are thanked for their patience and help during the long lasting production of this special issue. Special thanks to Phil Gibbard for his help and comments on this paper and his enthusiasm for the subject. We express our thanks to all the reviewers for their help and constructive comments on the papers.

\section{References}

Bos, J.A.A., Dambeck, R., Kalis, A.J., Schweizer, A., \& Thiemeyer, H., 2008 alaeoenvironmenttal changes and vegetation history of the northern Upper Rhine Graben (southwestern Germany) since the Lateglacial. Netherlands Journal of Geosciences 87/1: 67-90.

Busschers, F.S., Weerts, H.J.T., Wallinga, J., Cleveringa, P., Kasse, C., De Wolf,

H. \& Cohen, K.M., 2005. Sedimentary architecture and optical dating of Middle and late Pleistocene Rhine-Meuse deposits - fluvial response to climate change, sea-level fluctuation and glaciation. Netherlands Journal of Geosciences 84/1: 25-41.

Gibbard, P.L. \& Lautridou, J.P., 2003. The Quaternary history of the English Channel: an introduction. Journal of Quaternary Science 18: 195-199.

Gouw, M.J.P. \& Erkens, G., 2007. Architecture of the Holocene Rhine-Meuse delta (the Netherlands) - A result of changing external controls. Netherlands Journal of Geosciences 86/1: 23-54.

Hagedorn E.M. \& Boenigk, W., 2008. New evidences of the Pliocene and Quaternary sedimentary and fluvial history in the Upper Rhine Graben on basis of heavy mineral analyses. Netherlands Journal of Geosciences 87/1: 21-32.

Hoek, W.Z. \& Bohncke, S.J.P., 2002. Climatic and environmental events over the Last Termination, as recorded in the Netherlands: a review. Netherlands Journal of Geosciences 81: 123-137.

Kasse, C., Hoek, W.Z., Bohncke, S.J.P., Konert, M., Weijers, J.W.H., Van der

Zee, R.M. \& Cassee, M., 2005. Late Glacial fluvial response of the NiersRhine (western Germany) to climate and vegetation change. Journal of Quaternary Science 20(4): 377-394.

Kemna, H.A., 2008. A Revised Stratigraphy for the Pliocene and Lower Pleistocene Deposits of the Lower Rhine Embayment. Netherlands Journal of Geosciences 87/1: 91-105

Knipping, M., 2008. Pollenanalytical investigations on deep borings in the northern Upper Rhine Graben. Netherlands Journal of Geosciences 87/1 51-65.

Michon, L., Van Balen, R.T., Merle, O. \& Pagnier, H., 2003. The Cenozoic evolution of the Roer Valley Rift System integrated at a European scale. Tectonophysics. 367: 101-126.

Preusser, F., 2008. Characterisation and evolution of the River Rhine system. Netherlands Journal of Geosciences 87/1: 7-19.
Rolf, C., Hambach, U. \& Weidenfeller, M., 2008. Rock and palaeomagnetic evidence for the Plio-Pleistocene palaeoclimatic change recorded in Upper Rhine Graben sediments (Bohrung Ludwigshafen-Parkinsel). Netherlands Journal of Geosciences 87/1: 41-50.

Sissingh, W., 2006. Syn-kenematic palaeogeographic evolution of the West European Platform: correlation with Alpine plate collsion and foreland deformation. Netherlands Journal of Geosciences 85/2, 131-180.

Weidenfeller, M. \& Kärcher, T., 2008. Tectonic influence on fluvial preservation: Aspects of the architecture of Middle and Late Pleistocene sediments in the northern Upper Rhine Graben, Germany. Netherlands Journal of Geosciences 87/1: $33-40$

Westerhoff, W.E., Kemna, H.A. \& Boenigk, W., 2008. The confluence area of Rhine, Meuse, and Belgian rivers: Late Pliocene and Early Pleistocene fluvial history of the northern Lower Rhine Embayment. Netherlands Journal of Geosciences 87/1: 107-125. 